\title{
Activity of the $\beta 3$ Nicotinic Receptor Promoter Is a Marker of Neuron Fate Determination during Retina Development
}

\author{
Jean-Marc Matter, Lidia Matter-Sadzinski, and Marc Ballivet \\ Department of Biochemistry, Sciences II, University of Geneva, Geneva, Switzerland
}

\begin{abstract}
We have previously shown that transcription of the $\beta 3$ nicotinic receptor gene within the chick CNS is regulated by a promoter 143 base pairs (bp) in length. Here, we demonstrate that in the developing visual system this promoter is active in a subset of retinal cells, the majority of which are ganglion cells. Because the $\beta 3$ promoter is activated very early during retina development, it can provide a marker of ganglion cell induction and differentiation. Transfection of neuroretina explants enabled us to detect activity of the $\beta 3$ promoter in premigratory cells localized on the ventricular side of the retina. Double-labeling experiments showed that activation of the $\beta 3$ promoter takes place before the last S-phase, suggesting that this particular phenotypic trait is determined when precursor cells are still proliferating. The $\beta 3$ phenotype is induced in about onetenth of the total pool of retinal progenitor cells and is stable upon changing the cellular environment. Our study suggests that at the very early stages of retina neurogenesis, some lineage restrictions have already occurred in the population of retinal progenitor cells.
\end{abstract}

[Key words: nicotinic receptor, neuron-specific promoter, retina, retinal ganglion cells, neurogenesis, neuron transfection]

Neuroepithelia give rise to the large variety of neurons that reside within the CNS. The phenotype of central neurons is determined in a complex series of cellular decisions that narrow the developmental potential of precursor cells and lead to the generation of neuronal diversity (reviewed in McConnell, 1991). Because of its relatively simple stratified structure, well-established histogenesis, and small number of neuronal phenotypes, the retina provides a choice model for cellular and molecular studies on determination and differentiation of neuroepithelial cells (Dowling, 1987). Retrovirus-mediated gene transfer and dye microinjection experiments have been used to label retinal progenitor cells and to follow their differentiation (Turner and Cepko, 1987; Holt et al., 1988; Wetts and Fraser, 1988; Turner et al., 1990; Fekete et al., 1994). These experiments have led to the proposal that, in the retina of vertebrates, the majority of progenitor cells remain multipotential until their last mitosis, and

\footnotetext{
Received Mar. 17, 1995; revised May 10, 1995; accepted May 16, 1995.

We thank Joshua Sanes, Yves-Alain Barde, Tomas Roztocil, and an anonymous reviewer for insightful comments on the manuscript. This work was supported by the State of Geneva and by grants of the Swiss National Science Foundation.

Correspondence should be addressed to Jean-Marc Matter, Department of Biochemistry, Sciences II, 30 quai Ernest-Ansermet, 121 I Genève 4, Switzerland.

Copyright (C) 1995 Society for Neuroscience $0270-6474 / 95 / 155919-10 \$ 05.00 / 0$
}

that cell-type decisions are influenced by microenvironmental cues encountered by postmitotic cells before and during their migration. The cellular and molecular bases of the inductions that determine neuronal phenotypes in the vertebrate retina, as well as in other regions of the CNS, remain unknown largely because specific markers of early neurogenesis are lacking. Finding promoter elements that regulate transcription of neuron-specific genes expressed very early during development is therefore an important first step in deciphering the pathways that influence phenotype determination.

Of 10 related avian neuronal nicotinic acetylcholine receptor (nAChR) genes that have been characterized so far $(\alpha 2-\alpha 8$ and $\beta 2-\beta 4$; reviewed in Sargent, 1993), six (i.e., $\alpha 3, \alpha 4, \alpha 7, \alpha 8$, $\beta 2, \beta 3)$ are expressed in ganglion cells of the developing chick retina (Whiting et al., 1991; Matter-Sadzinski et al., 1992; Keyser et al., 1993; Hernandez et al., 1995; and this report). While the $\alpha 4, \alpha 7$, and $\beta 2$ subunits are widely distributed within the CNS, expression of the $\beta 3 \mathrm{nAChR}$ gene is confined to cells in the retina located in the ganglion cell layer (GCL) and in the inner half of the inner nuclear layer (INI). This highly restricted pattern of expression is effected by promoter elements in the $5^{\prime}$ flanking region of the $\beta 3$ gene, which are active only in a subpopulation of retinal cells (Hernandez et al., 1995).

In this report, we demonstrate that the $\beta 3$ promoter directs reporter gene expression to a subset of retinal neurons, the majority of which are ganglion cells. We show that $\beta 3$ promoter activity provides an appropriate marker to trace neuron-type determination during retina morphogenesis. Moreover, as the $\beta 3$ phenotype is induced on the ventricular side of the retina in premigratory cells that are still proliferating, our study suggests that the retinal neuroepithelium contains a subset of committed progenitor cells.

\section{Materials and Methods}

Probes. For in situ hybridization, we used 45-mer antisense and sense oligonucleotides corresponding to amino acids V364-Y378 of the $\beta 3$ subunit. Oligonucleotides were labeled to a final activity of 5-10 $10^{\circ}$ cpm/pmol by $3^{\prime}$ tailing, using $\left[\alpha^{35} \mathrm{~S}\right]-\mathrm{dATP}$ (New England Nuclear; $1200-1400 \mathrm{Ci} / \mathrm{mmol}$ ) as described by Hernandez et al. (1995).

Plasmid constructions. Plasmid pSVCAT was as described by MatterSadzinski et al. (1992). Constructions of plasmids p $\beta 3$ RSCAT, pß3RSlac, pSVlac were described in Hernandez et al. (199.5). The p $\beta 3$ RSlac and pSVlac plasmids contain the nlslac $Z$ gene, which codes for a $\beta$-galactosidase bearing the SV40 T-antigen nuclear localization signal (Kalderon et al., 1984).

Cell cultures, transfection, CAT, and $\beta$-galactosidase assays. All tissue culture reagents except as indicated were purchased from GIBCO/ BRL. Plasticware was from Nunc. Chick embryos were slaged according to Hamburger and Hamilton (1951). Retinal cells were prepared as previously described (Matter-Sadzinski et al., 1992). Briefly, eyes were excised from E3, E4, E5, E6, E7, E8, and E13 embryos, retinas (4-10 pairs) were dissected in $\mathrm{Ca}^{2+}$ - and $\mathrm{Mg}^{2+}$-free Hank's balanced salt so- 
Table 1. Activity of the $\beta 3$ promoter during neuroretina development

\begin{tabular}{|c|c|c|c|c|c|c|c|c|}
\hline \multirow[b]{2}{*}{ Stages } & \multicolumn{6}{|c|}{ Neuroretina } & \multicolumn{2}{|l|}{$\mathrm{PE}^{b}$} \\
\hline & $\begin{array}{l}\text { E3 } \\
(20)^{a}\end{array}$ & $\begin{array}{l}\text { E4 } \\
(23)\end{array}$ & $\begin{array}{l}\text { E5 } \\
(25-27)\end{array}$ & $\begin{array}{l}\text { E6 } \\
(29)\end{array}$ & $\begin{array}{l}\text { E8 } \\
(34)\end{array}$ & $\begin{array}{l}\text { E13 } \\
(39)\end{array}$ & $\begin{array}{l}\text { E5 } \\
(27)\end{array}$ & $\begin{array}{l}\text { E13 } \\
(39)\end{array}$ \\
\hline$(\beta 3 / \mathrm{SV} 40) \%$ & $<1$ & $5+1$ & $15+3$ & $14+3$ & $16+3$ & $10+2$ & 0 & 0 \\
\hline
\end{tabular}

Cells freshly dissociated from neuroretina and pigmented epithelium at different developmental stages were transfected with plasmids p 33 RSlac or pSVlac and plated on tissue culture chamber slides. Twenty-four hours after transfection, $\beta$-galactosidase-positive cells were revealed and counted in 10-15 grid areas that each contained about $2 \times 10^{3}$ positive cells upon transfection with pSVlac. Transfection rates with pSVlac were $15-20 \%$ at the different developmental stages. ( $\beta 3 / \mathrm{SV} 40$ ) $\%$ : ratio of $\beta 3$ to SV40 $\beta$-galactosidase positive cells, in percent.

"In parentheses: stages according to Hamburger and Hamilton (1951).

"Pigmented epithelium.

lution $\left(\mathrm{HBSS}^{-}\right.$) and incubated with $0.05 \%$ trypsin for $10 \mathrm{~min}$ (for E3$\mathrm{E} 8$ ) or with $0.1 \%$ trypsin for $20 \mathrm{~min}$ (for $\mathrm{E} 13$ ) at $37^{\circ} \mathrm{C}$. At the end of digestion deoxyribonuclease I (Boehringer) was added for 5 min (final concentration $30 \mu \mathrm{g} / \mathrm{ml}$ ) and then trypsin was inactivated by addition of fetal calf serum (FCS) to 5\%. E5 and E13 pigmented epithelia (from 8 to 12 eyes) were dissected and dissociated, respectively, like E5 and E13 neuroretinas. Cells were pelleted, rinsed with Opti-Mem medium, resuspended in Opti-Mem at densities as indicated below, and subjected to the transfection procedure.

Cell transfection was performed as described by Matter-Sadzinski et al. (1992). Plasmid DNA (5 $\mu \mathrm{g}$ in $100 \mu \mathrm{l}$ of Opti-Mem) was mixed with Lipofectin Reagent $(20 \mu \mathrm{g}$ diluted in $200 \mu \mathrm{l}$ of Opti-Mem) and transfection solution was added to $200 \mu \mathrm{l}$ of cell suspension containing $4-6 \times 10^{6}$ cells. After incubation for $45 \mathrm{~min}$ at $37^{\circ} \mathrm{C}$ transfection was stopped by adding $0.5 \mathrm{ml}$ of DMEM-20\% FCS and cells were plated either in a $35 \mathrm{~mm}$ culture dish precoated with poly-L-ornithine (PORN, $100 \mu \mathrm{g} / \mathrm{ml}$ ) for CAT assay or into the two chambers of a PORN-coated plastic or glass chamber slide (Lab-Tek) for $\beta$-galactosidase staining. In coculture experiments, transfected E5 retinal cells were mixed before plating with E5 tectal cells prepared as described in Matter-Sadzinski et al. (1992). Cells were cultured at $37^{\circ} \mathrm{C}$ in a humidified, $5 \% \mathrm{CO}_{2}$ atmosphere for 24,48 , or $72 \mathrm{hr}$. CAT assay and $\beta$-galactosidase staining procedures were performed as described by Hernandez et al. (1995).

Transfection of tissue explants and histology. To prepare explants, E4 neuroretinas and optic tecta were dissected in $\mathrm{HBSS}^{-}$at room temperature. At this stage of development, the retinal and tectal neuroepithclia are about $100 \mu \mathrm{m}$ thick. Prior to transfection, neuroretina and optic tectum explants were incubated for $60 \mathrm{sec}$ with $0.05 \%$ trypsin (one explant per well in four-well cluster dishes with $400 \mu \mathrm{l}$ of trypsin solution prepared in $\mathrm{HBSS}^{-}$and prewarmed at $37^{\circ} \mathrm{C}$ ). Thereafter, trypsin solution was removed, explants were rinsed three times with OptiMem medium, and were incubated for $14 \mathrm{hr}$ in $300 \mu \mathrm{l}$ of transfection solution containing $10 \mu \mathrm{g}$ plasmid DNA, $40 \mu \mathrm{g}$ Lipofectin prepared in Opti-Mem as described in Matter-Sadzinski et al. (1992). Transfection was stopped by adding $200 \mu \mathrm{l}$ of DMEM- $20 \%$ FCS, explants were rinsed three times with $200 \mu \mathrm{l}$ DMEM-20\% FCS and once with DMEM-10\% FCS. DMEM-10\% FCS $(400 \mu 1)$ was then added to each well and the floating explants were cultured for $48 \mathrm{hr}$ at $37^{\circ} \mathrm{C}$ in a humidified, $5 \% \mathrm{CO}_{2}$ atmosphere. The culture medium was removed, explants were rinsed twice with PBS, fixed in $2 \%$ formaldehyde, $0.4 \%$ glutaraldehyde (prepared in PBS) for $10 \mathrm{~min}$ at room tcmpcrature, rinsed twice with PBS, and stained for $3 \mathrm{hr}$ at $37^{\circ} \mathrm{C}$ in PBS (pH 7.2) containing $1 \mathrm{mg} / \mathrm{ml} \mathrm{X-GAL,} 4 \mathrm{~mm} \mathrm{~K}_{3} \mathrm{Fe}(\mathrm{CN})_{6}, 4 \mathrm{~mm} \mathrm{~K}_{4} \mathrm{Fe}(\mathrm{CN})_{6}$ and 2 $\mathrm{mM} \mathrm{MgCl}_{2}$. For histological analysis, explants were rinsed with PBS and postfixed in $4 \%$ formaldehyde for $30 \mathrm{~min}$, then they were washed in PBS, dehydrated in ethanol, cleared in xylene, and embedded in paraffin (Paraplast, Sherwood). Sections $(5 \mu \mathrm{m})$ were mounted on glass slides.

In situ hybridization. Whole eyes dissected on E5, E6, and E13 were embedded in OCT compound (Miles) and molded in tissue culture chambers, frozen in isopentane cooled to $-25^{\circ} \mathrm{C}$ on dry ice and stored at $-70^{\circ} \mathrm{C}$. Cryostat sections $(10 \mu \mathrm{m})$ of E5, E6, and E13 eyes were mounted on poly-L-Lysine-coated slides, pretreated, and hybridized as described by Aubry et al. (1993) and Hernandez et al. (1995).

Retrograde labeling of ganglion cells. Microinjection of fluorescent beads into the optic tectum and dissociation of retinas containing retrogradely labeled ganglion cells were described in Matter-Sadzinski et al. (1992).

Labeling with ${ }^{3} \mathrm{H}$-thymidine and autoradiography. $5-{ }^{3} \mathrm{H}$-thymidine
$(10 \mu \mathrm{Ci} / \mathrm{ml})$ was added to the culture medium of transfected cells for periods of time as indicated in the Results. To reveal radioactive labeling, the cells were stained for $\beta$-galactosidase, rinsed with PBS, fixed in $2 \%$ formaldehyde, $0.4 \%$ glutaraldehyde for $20 \mathrm{~min}$, rinsed with PBS, and dehydrated. The cells were then processed for autoradiography and exposed for $3 \mathrm{~d}$.

\section{Results}

$\beta 3$ Promoter activity is indicative of the ganglion cell phenotype

Promoter elements were identified in a DNA fragment extending 143 bp upstream from the transcription start site of the $\beta 3 n$ AChR gene (Hernandez et al., 1995). When this fragment was fused to lacZ (i.e., in p $\beta 3 R$ Slac) and transfected into freshly dissociated cells of differentiated retina on embryonic day 13 [E13, stage (39) of Hamburger and Hamilton, 1951], promoter activity was detected in $10 \pm 2 \%(n=10)$ of transfected neuroretinal cells (Tahle 1). In contrast, no $\beta$-galactosidase-positive nuclei were ever detected in transfected cells of the pigmented epithelium (Table 1), or in neuronal and non-neuronal cells isolated from different regions of the brain at several developmental stages (frequency $<10^{-5}$ of $\beta$-gal-positive cells transfected by the SV40 promoter; Hernandez et al., 1995). To identify and then to transfect retinal ganglion cells, we used the technique of retrograde labeling we have previously described (Matter-Sadzinski et al., 1992). Briefly, when fluorescent beads are microinjected into the superficial layers of the optic tectum on E10 (i.e., when the majority of ganglion cells extend their axons), they are retrogradely transported through the optic nerve into ganglion cell bodies. Seventy-two hours later, on E13, neuroretina fragments containing a high density of labeled ganglion cells were dissociated into single cells and transfected with pß3RSlac. Cells doubly labeled with beads and $\beta$-galactosidase could be detected after $24 \mathrm{hr}$, proving that the $\beta 3$ promoter is active in ganglion cells (Fig. 1). In the differentiated chick retina, ganglion cells represent $6-8 \%$ of the total cell population (Rager, 1980). In our hands, about $1 \%$ of all retinal cells are labeled by retrograde transport, and since this process exclusively labels ganglion cells, we conclude that between $1 / 8(13 \%)$ and $1 / 6$ $(17 \%)$ of ganglion cells are loaded with fluorescent beads. Remarkably, we find that among retinal cells with an active $\beta 3$ promoter, about $15 \%$ are loaded with beads, suggesting that the $\beta 3$ promoter is predominantly expressed in ganglion cells (Fig. 2). This important conclusion is only valid if the transfection procedure itself has no bias in favor of ganglion cells. To control for this, we transfected dissociated retinal cells with pSVlac and found that only $1 \%$ of transfected cells were double labeled. Thus, with pSVlac the proportion of double-labeled ganglion cells is the same as the proportion of bead-labeled ganglion cells 

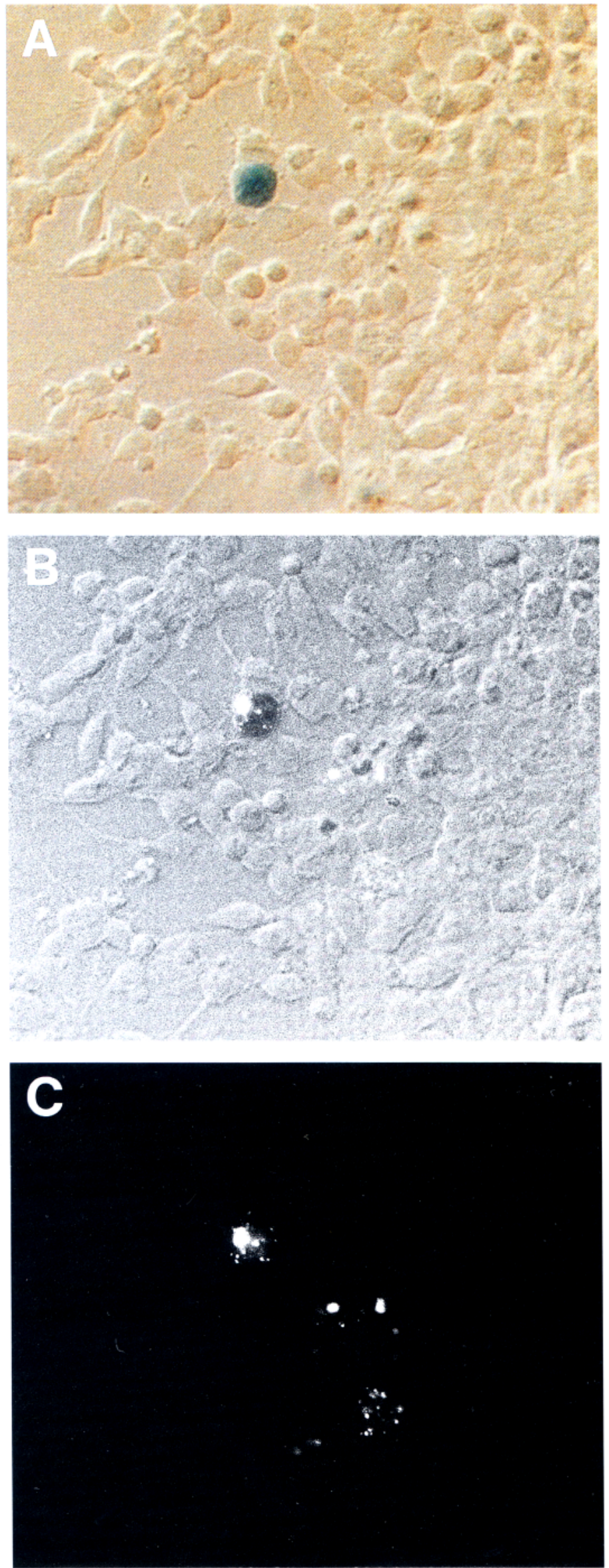

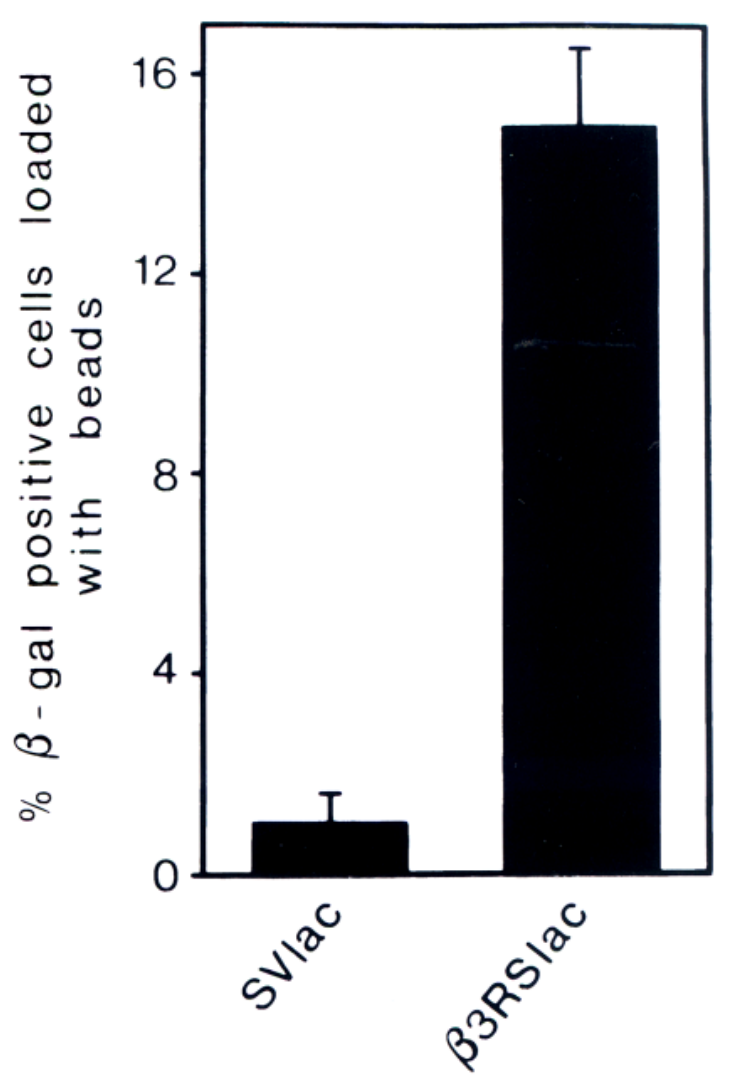

Figure 2. Enhanced $\beta 3$ promoter activity in the ganglion cell population. E13 retinas containing ganglion cells loaded with fluorescent beads were dissociated, transfected with p $\beta 3$ RSlac or pSVlac, and plated on chamber slides. After $24 \mathrm{hr}, \beta$-galactosidase- and $\beta$-galactosidase/ fluorescent-positive cells were counted in $10-15$ grid areas that each contained about $2 \times 10^{3} \beta$-galactosidase-positive cells upon transfection with pSVlac. Data were collected in four independent experiments.

in the total population, and we conclude that the transfection procedure does not favor ganglion cells.

Expression of the transfected $\beta 3$ promoter in ganglion cells faithfully reflects the transcription pattern of the endogenous $\beta 3$ gene as detected by in situ hybridization. Because the fraction of retinal cells that express the $\beta 3$ promoter $(10 \pm 2 \%$; Table 1) slightly exceeds the size of the ganglion cell population (6$8 \%$ ), we assume that a small fraction of cells with an active $\beta 3$ promoter have nonganglionic phenotypes. Amacrine cells are the only other retinal neurons where expression of the $\beta 3$ gene has been detected by in situ hybridization (Hernandez et al., 1995).

The $\beta 3$ transcripts accumulate in newly generated ganglion cells

Trace amounts of $\beta 3$ mRNAs are first detected by blot analysis in retina on E6. We have analyzed by in situ hybridization the $\leftarrow$

Figure 1. Activity of the $\beta 3$ promoter in tagged retinal ganglion cells. Rhodamine-labeled beads were microinjected in one optic lobe of an E10 embryo. On E13, fragments of the contralateral retina bearing high densities of fluorescent ganglion cells were dissociated, transfected with p $\beta 3$ RSlac, and plated on chamber slides. After $24 \mathrm{hr}, \beta$-galactosidasepositive cells were revealed. Ganglion cells stained with X-GAL and labeled with fluorescent beads were photographed with Nomarski $(A)$ or rhodamine $(C)$ optics. Note the two large ganglion cell bodies loaded with beads. $B$, Double-labeled ganglion cells were revealed using Nomarski and fluorescent optics. 


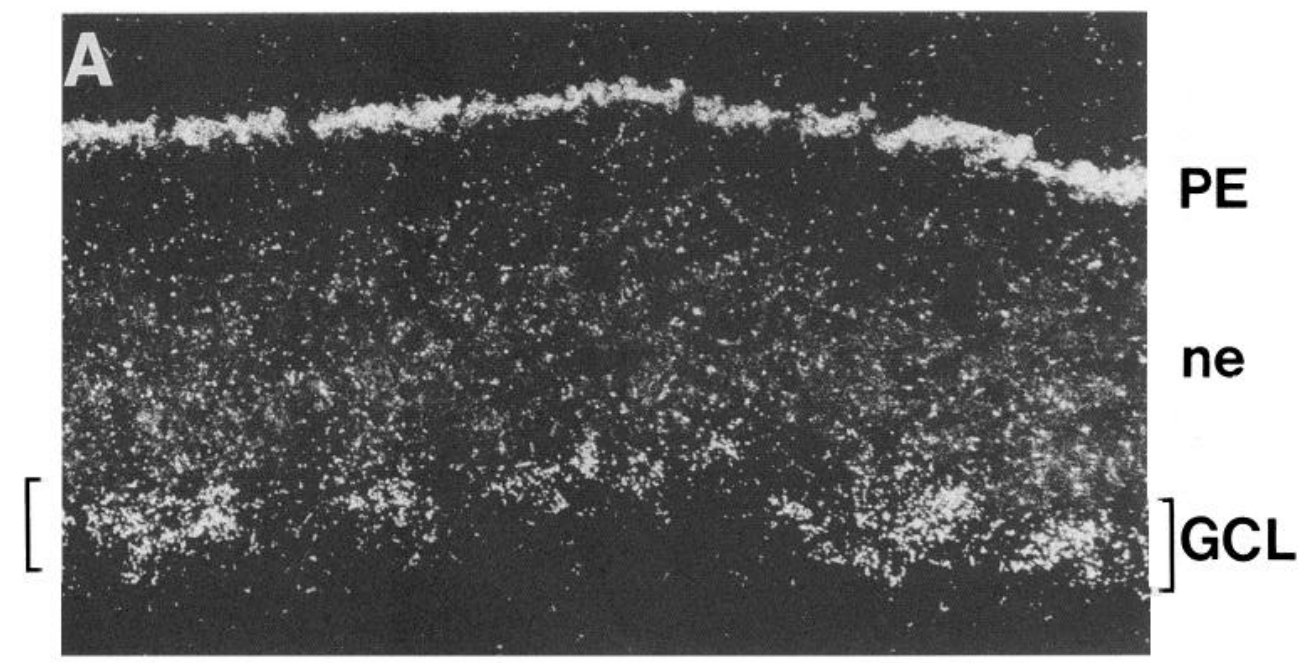

Figure 3. Distribution of the $\beta 3 \mathrm{n}$ AChR transcripts in E6 (29) retina. Sections across central $(A)$ and peripheral $(B)$ regions of the retina were mounted on the same slide and hybridized with ${ }^{35} \mathrm{~S}$-labeled antisense oligonucleotide probe. Exposure time was 3 weeks. Labeling above the background level was only detected in the GCL on the vitreous side of the central retina (A). This region contains newly generated postmigratory ganglion cells. $G C L$, ganglion cell layer; $P E$, pigmented epithelium; ne, neuroepithelium. Bar: $30 \mu \mathrm{m}$.



distribution of the $\beta 3$ transcripts in the central and peripheral regions of the retina at early stages of development. On E5, no labeling was detected in central or in peripheral retina. On E6 (29), $\beta 3$ transcripts start to accumulate in the central region of the retina, whose development is more advanced, and they are concentrated along the inner limiting membrane where newly generated postmitotic and postmigratory ganglion cells are located (Fig. 3).

\section{Induction of $\beta 3$ promoter activity in the neuroretina}

Accumulation of detectable amounts of $\beta 3$ transcripts in the retina on E6 indicates that the $\beta 3$ promoter is activated at an early stage of development. To determine the time course of this activation, retinal cells isolated on embryonic days $3,4,5,6,8$, and 13 were transfected with $p \beta 3$ RSlac or $\mathrm{p} \beta 3$ RSCAT. In experiments run in parallel, retinal cells were transfected with the corresponding control plasmids pSVlac or pSVCAT. The fractions of cells with $\beta$-galactosidase-positive nuclei and the levels of CAT activity in the cytosolic fractions were determined 24 hr after transfection (Table 1, Fig. 4). Only a few $\beta$-galactosidase-positive nuclei were detected in cells transfected with p $\beta 3$ RSlac on E4 (23), whereas on E5 (25), the $\beta 3$ promoter became active in about $15 \%$ of transfected cells. Similar proportions of $\beta$-galactosidase-positive nuclei were found in cells transfected on E6 and E8, and slightly less on E13 (Table 1).
Ganglion-like cells with an active $\beta 3$ promoter were frequently observed in dissociated retinas transfected on E5 or E6 (Fig. $6 A)$. In contrast, no promoter activity was ever detected in cells from E5 pigmented epithelium and in cells from E5 tectal neuroepithelium (frequency $<10^{-5}$ of blue cells obtained upon transfection by the SV40 promoter; Table 1 and Hernandez et al., 1995).

In retinal cells transfected with $\mathrm{p} \beta 3$ RSCAT, expression of the reporter gene was first detected on E4. Thereafter, CAT activity increased about 10-fold to culminate on E5 and then decreased rather abruptly to attain a stable low level between E8 and E13 (Fig. 4). Because similar fractions of transfected cells expressed $\beta 3$ lacZ at different developmental stages starting from E5 (Table $1)$, this burst of CAT gene expression has to result from a transient increase in $\beta 3$ promoter activity within the same stable proportion of retinal cells. In cells transfected with the control plasmid pSVCAT, constant CAT activities were detected at the different developmental stages. Activation of the $\beta 3$ promoter thus takes place in the retina around E4 (23), and the burst of activity of the $\beta 3$ promoter coincides with the period of development when the majority of ganglion cells are generated.

\section{Activity of the $\beta 3$ promoter in retina explant}

To analyze the topographic distribution of $\beta 3$ promoter activation within neuroretinal tissue, we attempted to transfect whole 

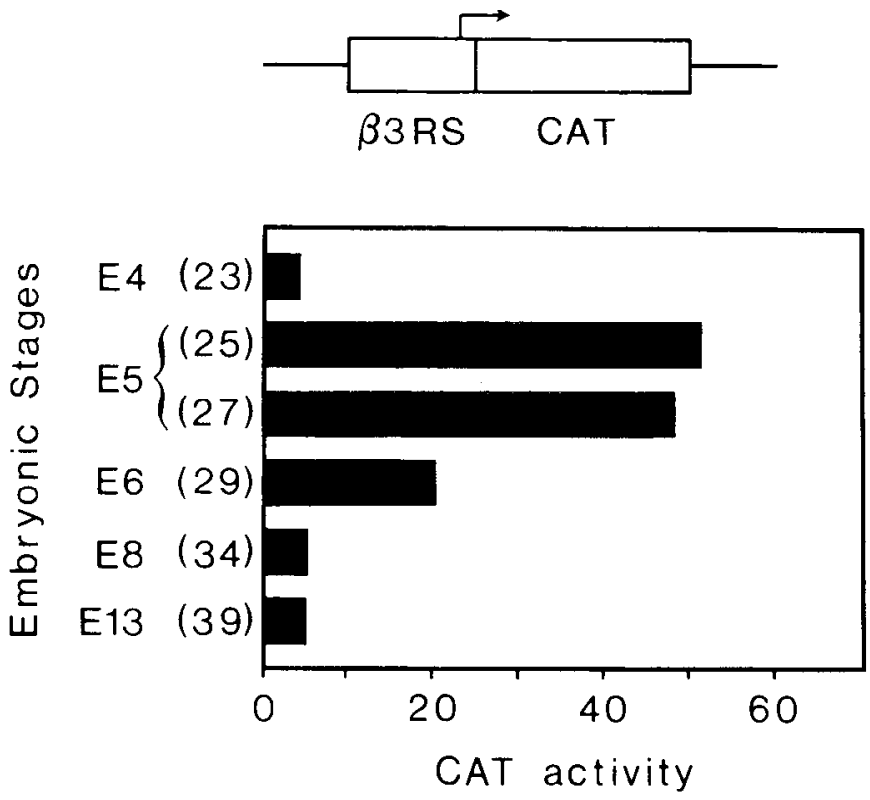

Figure 4. Activity of the $\beta 3$ promoter during retina development. The $\beta 3$ promoter (RS fragment) fused to the CAT gene was transfected into cells isolated at different stages of retina development. Twenty-four hours after transfection, cells were processed for CAT assay. The CAT activity obtained upon transfection by pSVCAT is arbitrarily set at 100 for each developmental stage. Activities of the $\beta 3$ promoter are given relative to this value. Activity of the SV40 early promoter in arbitrary CAT units per $\mu \mathrm{g}$ protein was similar at the different stages of retina development. In parentheses, stages according to Hamburger and Hamilton (1951).

retina explants. Neuroretinas dissected on E4 were transfected with p 33 RSlac as described in Materials and Methods and cultured as floating explants for $48 \mathrm{hr}$, whereupon they were stained for $\beta$-galactosidase. The transfection rate in the explants was much lower than in dissociated cells, yet many cells with an active $\beta 3$ promoter were observed (Fig. $5 A$ ), while no positive cells were ever detected after transfection of E4 optic tectum explants with the same plasmid construct. The distribution of $\beta$-galactosidase-positive cells through the different layers of the explants was then analyzed on tissue sections (Fig. 5B,C). In vivo, cells proliferate on the ventricular side of the retina. A postmitotic ganglion cell then extends a process through the thickness of the retina toward the inner limiting membrane, and its nucleus migrates within the process toward the vitreous side of the retina, where ganglion cell bodies form the GCL (Ramon y Cajal, 1911; Rager, 1980; Prada et al., 1981). In vitro, a GCL was also generated on the vitreous side of retina explants, and cells in this layer had the typical spheroidal appearance of ganglion cells, quite different from the densely packed fusiform cells found in the neuroepithelium. In transfected explants, postmigratory ganglion cells with $\beta$-galactosidase-positive nuclei were detected in the GCL (Fig. 5B). Moreover, positive nuclei were also found in cells located in the proliferative zone on the ventricular side of the retina (Fig. $5 C$ ), indicating that the $\beta 3$ promoter is already active in premigratory retinal cells. This experiment did not reveal whether these premigratory cells are mitotic or postmitotic and whether $\beta$-galactosidase-positive ganglion cells nestled in the GCL had been transfected before they left the proliferative zone or later, when they had already reached the vitreous side of the retina.

\section{Activation of the $\beta 3$ promoter precedes the last $S$-phase}

To determine which proportion of postmitotic retinal cells express the $\beta 3$ promoter, cells isolated on embryonic days 4,5 , or 13 were transfected with $\mathrm{p} \beta 3 \mathrm{RS}$ lac or pSVlac, and ${ }^{3} \mathrm{H}$-thymidine was added to the culture medium immediately after plating. Twenty-four hours later, $\beta$-galactosidase-positive nuclei were revealed and radioactivity was detected by autoradiography (Table 2, Fig. 6B). On E13, cells are postmitotic and no radioactively labeled cells were observed. On E4 and E5, respectively, about half and one-third of the cells with an active $\beta 3$ promoter were radioactively labeled, whereas upon transfection by $\mathrm{pSVlac}$ the large majority of $\beta$-galactosidase-positive cells had radioactive nuclei (Table 2). Similar high proportions of retinal cells proliferate in vivo at the corresponding stages (Prada et al., 1991). The ganglion cells are the first retinal neurons to withdraw from the mitotic cycle, and about $30 \%$ of them are postmitotic by embryonic day 4 . In contrast, less than $3 \%$ of amacrine, horizontal, bipolar, and photoreceptor cells are postmitotic at this stage (Prada et al., 1991). Thus, the high percentage of postmitotic cells with $\beta$-galactosidase-positive nuclei at E4 and E5 confirms that the $\beta 3$ promoter is mainly active in ganglion cells (Fig. 6A). Next, we asked whether the $\beta 3$ promoter is active in proliferating retinal precursor cells. Indeed, when retinal cells transfected on E5 were pulse labeled for $3 \mathrm{hr}$ after $21 \mathrm{hr}$ in culture, about one-tenth of blue cells had radioactive nuclei (Fig. $6 C, D$ and Table 2). This population of double-labeled cells obviously went in $S$-phase after activation of the $\beta 3$ promoter. In addition, we observed cells in telophase whose daughter nuclei were both $\beta$-galactosidase-positive (Fig. $6 E$ ). Such mitotic figures were never seen in cells transfected at E13, when the whole population has withdrawn from the mitotic cycle, indicating that the telophase figures seen at E5 are not a cell-fusion artifact induced by the lipofection procedurc.

\section{Activity of the $\beta 3$ promoter and cell commitment}

A cell is said to be committed if it continues to differentiate autonomously upon changing its environment (reviewed in McConnell, 1991). To test whether activity of the $\beta 3$ promoter is affected in the absence of the eye's surrounding tissues (e.g., pigmented epithelium, choroid, vitreous body), whole neuroretinas were dissected on E4 (23) and cultured as floating explants for $2 \mathrm{~d}$. Cells dissociated from the explants were transfected with p 33 RSlac, p $\beta 3$ RSCAT, and with the corresponding control plasmids. Expression levels of the reporter genes were determined $24 \mathrm{hr}$ later and compared with those in retinal cells isolated on F6 and transfected in parallel (Fig. 7A). No significant differences in activities of the $\beta 3$ promoter were found between explanted and in vivo retinas.

In another series of experiments, we tested the influence of cell-cell interactions on $\beta 3$ promoter activity. When retinal cells were transfected with $\mathrm{p} \beta 3 \mathrm{RSlac}$ or pSVlac on E5 (25) and cultured at high or low densities, similar proportions of transfected cells with an active $\beta 3$ promoter were found in the two culture conditions after 24,48 , or $72 \mathrm{hr}$ of incubation in vitro (Fig. $7 B$ ). Moreover, activity of the $\beta 3$ promoter was not altered by an ectopic environment: when cells from E5 retina transfected with p 33 RSlac were cocultured for $48 \mathrm{hr}$ with a 10-fold excess of 5 -d-old tectal cells, they displayed the same proportion of lac $Z$ positive cells as those cocultured with an excess of 5 -d-old retinal cells (Fig. 7C). These experiments show that changing the cellular environment has no significant effect on $\beta 3$ promoter 

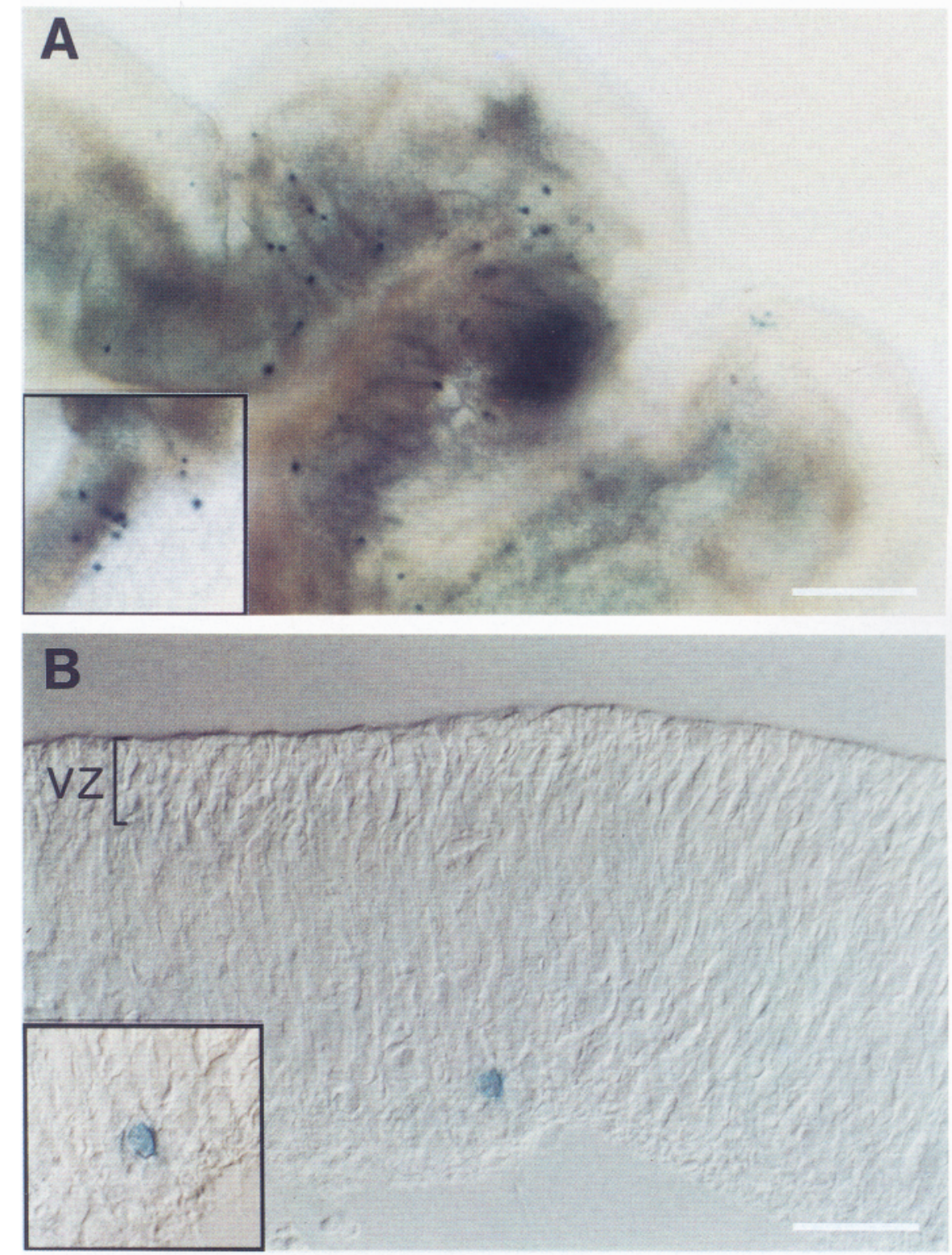

Figure 5. Distribution of $\beta 3$ promoter activity in neuroretina explants. Whole neuroretinas isolated on E4 (23) were transfected with $\mathrm{p} \beta 3 \mathrm{RS}$ lac, cultured for $48 \mathrm{hr}$ as floating explants and processed to reveal $\beta$-galactosidase-positive cells $(A)$. To analyze the distribution of these cells in the different layers of the neuroretina, explants were sectionned and photographed with Nomarski optics $(B$ and $C$ ). The vitreal (inner) surfaces are towards the bottom and the ventricular (outer) surfaces are towards the top. $B$, Cells with $\beta$-galactosidasepositive nuclei were found on the vitreous side and had the typical spheroidal appearance of ganglion cells. $C$, Positive nuclei were also detected in premigratory cells localized in the ventricular zone $(V Z)$. Insets show $\beta$-galactosidase-positive cells at higher magnification. Bars: $80 \mu \mathrm{m}(A), 30 \mu \mathrm{m}$ $(B$ and $C)$.

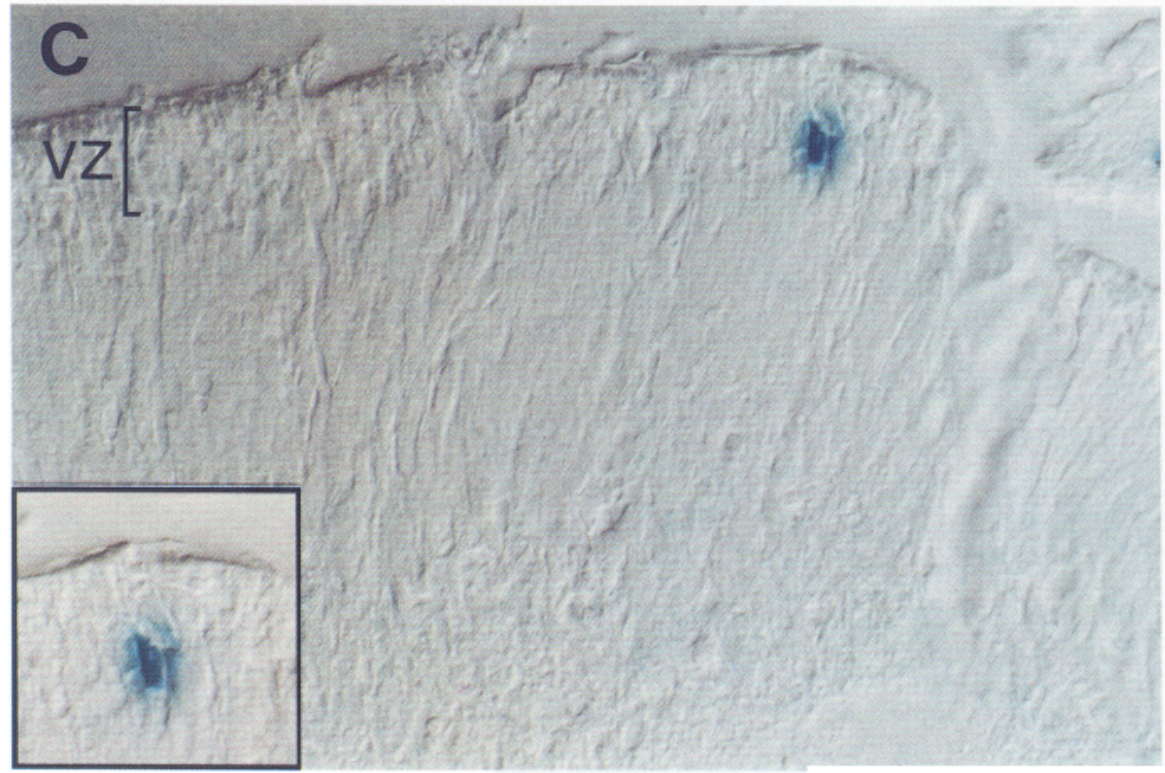


Table 2. $\beta 3$ promoter activity in mitotic retinal cells (\%)

\begin{tabular}{|c|c|c|c|c|c|}
\hline & \multirow[b]{2}{*}{$\beta 3 / \mathrm{SV} 40$} & \multicolumn{2}{|l|}{$\beta 3$} & \multicolumn{2}{|c|}{ SV40 } \\
\hline & & ${ }^{3} \mathrm{H}+$ & ${ }^{3} \mathrm{H}-$ & ${ }^{3} \mathrm{H}+$ & ${ }^{3} \mathrm{H}-$ \\
\hline $\mathrm{NR}_{\mathrm{EA}}\left({ }^{3} \mathrm{HdT}_{0-24 \mathrm{~h}}\right)$ & $5 \pm 1$ & 50 & 50 & 85 & 15 \\
\hline $\mathrm{NR}_{\mathrm{ES}}\left({ }^{3} \mathrm{HdT}_{0-24 \mathrm{~h}}\right)$ & $15 \pm 3$ & 36 & 64 & 62 & 38 \\
\hline $\mathrm{NR}_{\mathrm{ES}}\left({ }^{3} \mathrm{HdT}_{21-24 \mathrm{~h}}\right)$ & $15 \pm 3$ & 10 & 90 & 20 & 80 \\
\hline $\mathrm{NR}_{\mathrm{E} 13}\left({ }^{3} \mathrm{HdT}_{0-24 \mathrm{~h}}\right)$ & $10 \pm 2$ & 0 & 100 & $<1$ & 99 \\
\hline
\end{tabular}

Retinal cells were transfected with plasmids p $\beta 3$ RSlac or pSVlac and plated on chamber slides. ${ }^{3} \mathrm{HdT}$ was added to the culture medium either immediately after plating or $21 \mathrm{hr}$ later. $\beta$-Galactosidase-positive nuclei were revealed 24 $\mathrm{hr}$ after transfection and cells were processed for autoradiography. Exposure time was $4 \mathrm{~d}$. Cells were viewed and counted with Nomarski optics in 10-15 grid areas that each contained about $2 \times 10^{3}$ positive cells upon transfection with pSVlac.

activity in retinal cells, suggesting that this activity is a determined feature of committed precursor cells.

\section{Discussion}

The experiments reported here indicate that a sequence of 143 bp located in $5^{\prime}$ of the $\beta 3 \mathrm{nAChR}$ gene contains promoter ele- ments necessary and sufficient to direct reporter gene expression to a subpopulation of retinal neurons, the majority of which are ganglion cells. Taking $\beta 3$ promoter activity as a phenotypic trait of ganglion cells, we provide evidence that the retinal neuroepithelium contains a subset of progenitor cells committed to ganglion cell fates prior to their last S-phase.

\section{Neuron-type specificity of the $\beta 3$ promoter}

By transfection of retinal cells, we demonstrated that the $\beta 3$ promoter is predominantly active in ganglion cells that have been identified in vivo by retrograde transport of fluorescent beads. This restricted promoter activity is in good agreement with the distribution of the $\beta 3$ transcripts and protein within the GCL. The fraction of retinal cells with an active $\beta 3$ promoter, however, slightly exceeds the proportion of ganglion cells, indicating that this promoter may also be active in a small subset of retinal cells of a different phenotype. The amacrine neurons are the only other retinal cells where expression of the $\beta 3$ gene has been detected by in situ hybridization (Hernandez et al., 1995). Ultrastructural studies by Hinds and Hinds (1983) have revealed that, during retina development, a subset of amacrine
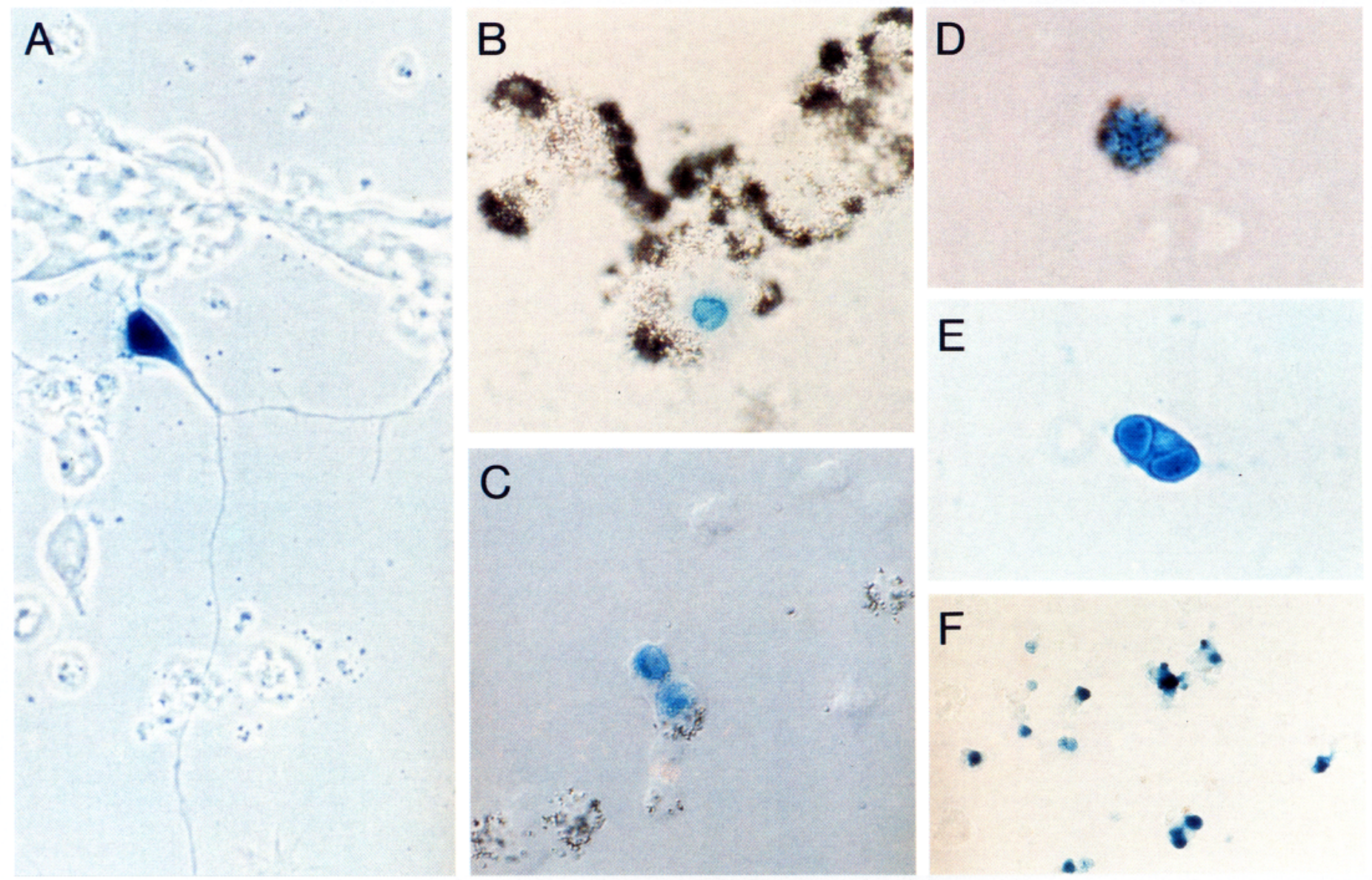

Figure 6. Activity of the $\beta 3$ promoter in dissociated retinal cells. Retinal cells isolated on E5 $(B, C, D$, and $E)$ or E6 $(A)$ were transfected with $\mathrm{p} \beta 3$ RSlac, and plated on chamber slides. ${ }^{3} \mathrm{H}$-dT was added to the culture medium immediately after plating $(B)$ or $21 \mathrm{hr}$ later $(C$ and $D)$. $\beta$ -Galactosidase-positive nuclei were revealed $24 \mathrm{hr}$ after plating and the chamber slides $(B, C$, and $D)$ were processed for autoradiography. Exposure time was $3 \mathrm{~d}$. $A$, Phase-contrast micrograph of a ganglion-like cell with a $\beta$-galactosidase-positive nucleus. $B$, After incubation of transfected E5 cells with ${ }^{3} \mathrm{H}$-dT for $24 \mathrm{hr}$, the majority of cells were radioactive, but unlabeled cells with $\beta$-galactosidase-positive nuclei were detected. $C$, Nomarski micrograph of retinal cells after a 3 hr radioactive pulse. $D$, Cells with double-labeled nuclei ( $\beta$-galactosidase- and ${ }^{3} \mathrm{H}$-dT-positive) were detected after a $3 \mathrm{hr}$ radioactive pulse. E, A mitotic cell in telophase. Note that the two daughter nuclei and the cytoplasm are stained, suggesting that nucleus reconstruction took place after activation of the $\beta 3$ promoter. $F$, Low magnification micrograph of retinal cells isolated on E5 and transfected with the control plasmid pSVlac. Fifteen to $20 \%$ of the cells were transfected. 

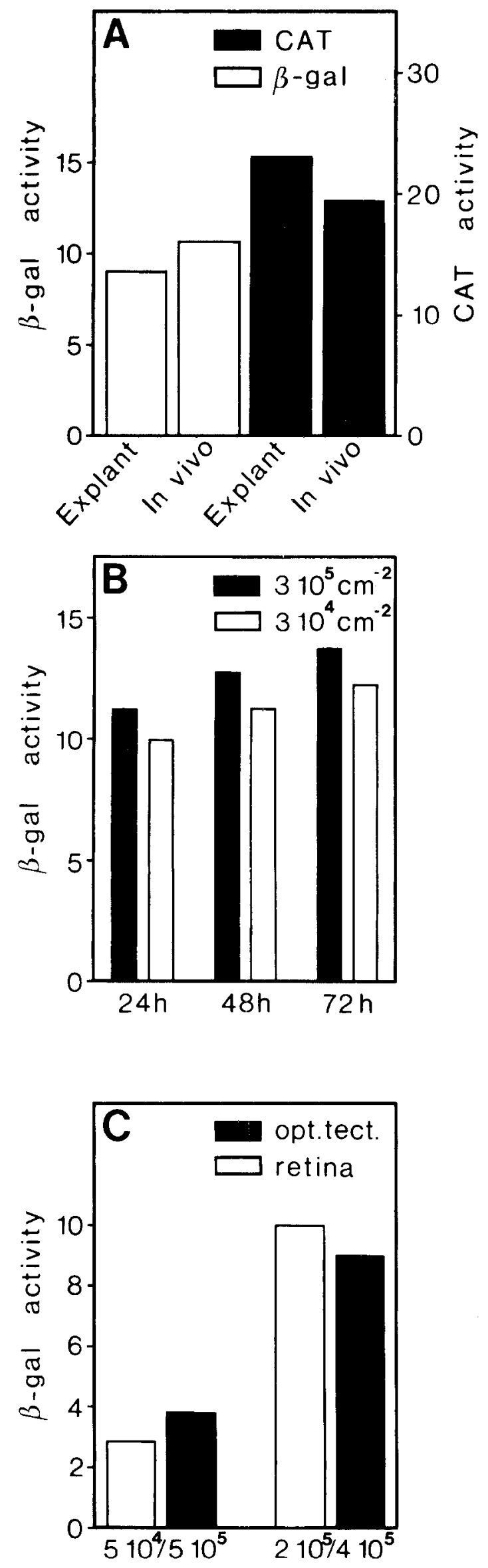

neurons is generated by morphologic transformations of ganglion cells that include axon loss and outward migration of the cell body to the inner half of the INL. Thus, expression of $\beta 3$ in ganglion cells and in some amacrine neurons may reflect the closely related origin of these two retinal phenotypes. In accordance with the expression pattern of the $\beta 3$ gene, no activity of the $\beta 3$ promoter has been detected in any other cell population of the developing chick visual system. In the PNS, $\beta 3$ is expressed in the trigeminal ganglion but not in the ciliary ganglion (Hernandez et al., 1995). Upon transfection of trigeminal and ciliary neurons, p $\beta 3 R$ Rlac was consistently found to be expressed only in trigeminal neurons, although cells of both ganglia were transfected at similar rates with the control plasmid pSVlac (Matter-Sadzinski and Matter, unpublished data). These results ascertain that the cloned $\beta 3$ promoter faithfully reproduces the specificity of the endogenous $\beta 3$ gene.

The stringent promoter selectivity exhibited by a short sequence of 143 bp suggests that this fragment contains neuronspecific cis-acting regulatory elements sufficient to ensure accurate discrimination among the large repertoire of neurons. Sequence analysis revealed the presence of classical promoter elements such as properly positioned T $\Lambda \mathrm{T} \Lambda$ and $\mathrm{C} \Lambda \Lambda \mathrm{T}$ boxes, as well as several putative binding sites for transcription factors (Hernandez et al., 1995). Site-directed mutations indicate that both the integrity and position of an E-box (a binding site for basic helix-loop-helix proteins) is essential for activity of the $\beta 3$ promoter in retinal cells (Roztocil et al., in preparation). Because of its stringent specificity, the $\beta 3$ promoter should provide a powerful tool to identify transcription factors that regulate neuron-specific patterns of gene expression.

Most of the neural genes characterized so far encode proteins that are ubiquitous in the nervous system, and only a few neuron-type specific promoters have been identified in vertebrates (reviewed in Mandel and McKinnon, 1993). Cis-acting regulatory elements that drive transcription of the opsin gene in photoreceptor cells (Lem et al., 1991; Zack et al., 1991) and the $L 7 /$ $p c p-2$ gene in Purkinje cells (Oberdick et al., 1990; Vandaele et al., 1991) have been detected in large fragments of genomic DNA. A finer mapping of the $5^{\prime}$ flanking region of the human red visual pigment gene has identified a $0.6 \mathrm{~kb}$ sequence essential for photoreceptor-specific expression (Wang et al., 1992). Although binding sites for the Olf- 1 transcription factor have been localized in the vicinity of five olfactory-specific genes (Wang and Reed, 1993), neuron-specific genes coexpressed in

$\leftarrow$

Figure 7. Stability of the $\beta 3$ promoter activity upon changing retinal cell environment. A, Neuroretinas were dissected on E4 (23) and cultured as floating explants for $48 \mathrm{hr}$. These explanted retinas and freshly dissected E6 retinas were then dissociated and transfected with p $\beta 3$ RSlac, p $\beta 3$ RSCAT, pSVlac, or pSVCAT. Twenty-four hours after transfection, cells were processed for CAT assay, or $\beta$-galactosidasepositive cells were revealed and counted. $\beta$-Galactosidase-positive cells and CAT activities are expressed as a percentage of the corresponding SV40 controls. $B$. Retinal cells isolated on E5 (25) were transfected with $\mathrm{p} \beta 3 \mathrm{R}$ Slac or pSVlac and plated on chamber slides at high $(3 \times$ $\left.10^{5} \mathrm{~cm}^{-2}\right)$ or low densities $\left(3 \times 10^{4} \mathrm{~cm}^{-2}\right)$. $\beta$-Galactosidase-positive cells were revealed and counted 24,48 , or $72 \mathrm{hr}$ later, and expressed as a percentage of positive cells in the SV40 control. $C, 5 \times 10^{4}$ or 2 $\times 10^{5}$ retinal cells isolated on E5 (26) were transfected with $\mathrm{p} \beta 3 \mathrm{RSlac}$, then they were mixed and plated on chamber slides with, respectively, $5 \times 10^{5}$ or $4 \times 10^{5}$ cells isolated either from E5 optic tectum or E5 retina. $\beta$-Galactosidase-positive cells were counted $48 \mathrm{hr}$ later. The number of $\beta$-galactosidase-positive cells obtained with the mixture of $2 \times 10^{5 / 4} \times 10^{5}$ retinal cells is arbitrarily set at 10 . 
the same neuron subpopulation do not necessarily share regulatory elements. For instance, in differentiated retina activities of the $\beta 3$ and $\alpha 7 \mathrm{nAChR}$ promoters are restricted to retinal ganglion cells, although there is no homology whatever between their sequences (Matter-Sadzinski et al., 1992; Hernandez et al., 1995).

\section{Induction of the $\beta 3$ phenotype precedes the last $S$-phase}

In the course of neurogenesis, ganglion cells are the first retinal neurons to withdraw from the cell cycle. The $\beta 3$ promoter is activated in the retina as early as on $\mathrm{E} 4$, and at this stage, more than $97 \%$ of cells that will differentiate in amacrine, horizontal, bipolar, and photoreceptor cells are still proliferating (Prada et al., 1991). Thus, the high proportions of $\beta$-galactosidase-positive postmitotic cells detected on E4 and E5 indicatc that activity of the $\beta 3$ promoter is mainly confined to the ganglion cell population. Analysis of the topographic distribution of this early activation within neuroretina explants transfected with $p \beta 3 R S l a c$ reveals the presence of $\beta$-galactosidase--positive cells in newly generated postmigratory cells of the GCL, the cell layer in which $\beta 3$ transcripts are localized in vivo by in situ hybridization. Furthermore, $\beta 3$ promoter activity was detected in premigratory cells located in the proliferative zone of the retina and pulselabeling experiments demonstrated that some retinal precursors enter S-phase with an active $\beta 3$ promoter. The absence of detectable amounts of $\beta 3$ transcripts on the ventricular side of the retina suggests that, soon after $\beta 3$ promoter activation, the cells withdraw from the mitotic cycle, migrate away from the proliferative zone, and accumulate on the vitreous side of the retina. Our experiments cannot exclude the possibility that the $\beta 3$ phenotype may be present in precursor cells and in postmitotic neurons coincidentally, rather than by continuous inheritance of a differentiated phenotype. However, it seems unlikely that the $\beta 3$ promoter, after being first activated in a very small subset of proliferating retinal cells, is then turned off when these cells withdraw from the mitotic cycle and is simultaneously activated in a different, unrelated subset of postmitotic retinal cells. We therefore believe that aclivation of the $\beta 3$ promoter represents one of the earliest events in ganglion cell determination. Interestingly, the $\alpha 7$ nAChR promoter exhibits a very different behavior during retina neurogenesis. This promoter is first activated in the large majority of retinal cells and then, in the course of development, its activity becomes restricted to a subset of ganglion cells (Matter-Sadzinski et al., 1992).

Neither cellular interactions nor ectopic cell environments influenced activation of the $\beta 3$ promoter, indicating that $\beta 3$ expression reflects the commitment of a progenitor subset. The presence of committed progenitor cells within the retinal neuroepithelium has been a controversial issue (Williams and Goldowitz, 1992), and our study provides evidence that important cell fate decisions are made before retinal precursors become postmitotic. Consistent with this view, Waid and McLoon (1995) have shown that expression of the chick ganglion cell antigen RA4 begins in premigratory cells immediately after the last mitosis.

In the mammalian cerebral cortex, transplantation experiments have shown that neurons become committed to particular laminae during their last cell cycle (McConnell, 1991; McConnell and Kaznowski, 1991). Luskin et al. (1993) and Mione et al. (1994) used retroviral-mediated gene transfer to demonstrate that in the rat cortical neuroepithelium distinct progenitor subsets generate pyramidal and nonpyramidal neurons. In the retina of vertebrates, lineage studies conducted to date indicate that the majority of progenitor cells are multipotent. Mapping of cell fate in rodent and amphibian retinas has revealed that clonally related descendants of individual precursor cells form radial clusters spanning the different layers of adult retina (Turner and Cepko, 1987; Wetts and Fraser, 1988; Holt et al., 1988; Turner et al., 1990). These results suggested that a single multipotent progenitor generates most retinal cell types and led to the proposal that cell-type determination in retina is lineage independent. In this view, the cessation of mitosis and cell-type decisions are sequential, independent events controlled by environmental interactions. However, as noted by Guillemot and Cepko (1992), lineage data concerning ganglion cells in mammalian retina are difficult to interpret due to the limited number of clones containing marked ganglion cclls.

Several studies point to a role for the local environment in promoting the in vitro differentiation of rod photoreceptors ( $\mathrm{Al}$ tshuler and Cepko, 1992; Reh, 1992). Identification of factors in the medium of cultured retinal cells that induce the rod phenotype (Altshuler et al., 1993) implies that signals released by retinal cells generated earlier in development may provide precursor cells with instructions about what cell type to produce. Ganglion cells are the earliest neurons to be generated during retina morphogenesis and they may contribute to the formation of specific environments that will influence the differentiation of retinal neurons generated at a later date.

In conclusion, we propose that the retinal neuroepithelium contains a complex mixture of progenitors whose potency may change during development as a result of interactions between autonomous programs and variable environmental influences: commitment to the ganglion cell phenotype is an instance of early restriction in developmental potency, while progenitors of late neurons may retain their equipotency to produce a range of other retinal phenotypes until much later in development.

\section{References}

Altshuler D, Cepko C (1992) A temporally regulated, diffusible activity is required for rod photoreceptor development in vitro. Development 114:947-957.

Altshuler D, Lo Turco JJ, Rush J, Cepko C (1993) Taurine promotes the differentiation of a vertebrate retinal cell type in vitro. Development 119:1317-1328.

Aubry J-M, Schulz M-F, Pagliusi S, Schulz P, Kiss JZ (1993) Coexpression of dopamine $D 2$ and substance $P$ (neurokinin-1) receptor mRNAs by a subpopulation of cholinergic neurons in the rat striatum Neuroscience 53:417-424

Dowling JE (1987) The retina. Cambridge, MA: Belknap Press of Harvard UP.

Fekete DM, Perez-Miguelsanz J, Ryder EF, Cepko C (1994) Clonal analysis in the chicken retina reveals tangential dispersion of clonally related cells. Dev Biol 166:666-682.

Guillemot F, Cepko CL (1992) Retinal fate and ganglion cell differentiation are potentiated by acidic FGF in an in vitro assay of early retinal development. Development 114:743-754.

Hamburger V, Hamilton HL (1951) A series of normal stages in the development of the chick embryo. J Morphol 88:49-92.

Hernandez M-C, Erkman L, Matter-Sadzinski L, Roztocil T, Ballivet M, Matter J-M (1995) Characterization of the nicotinic acetylcholine receptor $\beta 3$ gene: its regulation within the avian nervous system is effected by a promoter $143 \mathrm{bp}$ in length. J Biol Chem 270:32243233 .

Hinds JW, Hinds PL (1983) Development of retinal amacrine cells in the mouse embryo: evidence for two modes of formation. J Comp Neurol 213:1-23.

Holt CE, Bertch TW, Ellis HM, Harris WA (1988) Cellular determination in the Xenopus retina is independent of lineage and birth date. Neuron 1:15-26. 
Kalderon D, Roberts BL, Richardson WD, Smith AE (1984) A short amino acid sequence able to specify nuclear location. Cell 39:499509.

Keyser KT, Britto LRG, Schoepfer R, Whiting P, Cooper J, Conroy W, Brozozowska-Prechti A, Karten HJ, Lindstrom J (1993) Three subtypes of $\alpha$-bungarotoxin-sensitive nicotinic acetylcholine receptors are expressed in chick retina. J Neurosci 13:442-454.

Lem J, Applebury ML, Falk JD, Flannery JG, Simon MI (1991) Tissue specific and developmental regulation of rod opsin chimeric genes in transgenic mice. Neuron 6:201-210.

Luskin MB, Parnavelas JG, Barfield JA (1993) Neurons, astrocytes, and oligodendrocytes of the rat cerebral cortex originate from separate progenitor cells: an ultrastructural analysis of clonally related cells. J Neurosci 13:1730-1750.

Mandel G, McKinnon D (1993) Molecular basis of neural-specific gene expression. Annu Rev Neurosci 16:323-345.

Matter-Sadzinski L, Hernandez M-C, Roztocil T, Ballivet M, Matter J-M (1992) Neuronal specificity of the $\alpha 7$ nicotinic acetylcholine receptor promoter develops during morphogenesis of the central nervous system. EMBO J 11:4529-4538.

McConnell SK (1991) The generation of neuronal diversity in the central nervous system. Annu Rev Neurosci 14:269-300.

McConnell SK, Kaznowski CE (1991) Cell cycle dependence of laminar determination in developing neocortex. Science 254:282-285.

Mione MC, Boardman P, Harris B, Parnavelas JG (1994) Lineage analysis reveals neurotransmitter (GABA or glutamate) but not calciumbinding protein homogeneity in clonally related cortical neurons. $J$ Neurosci 14:107-123.

Oberdick J, Smcyne RJ, Mann JR, Zackson S, Morgan JI (1990) A promoter that drives transgene expression in cerebellar purkinje and retinal bipolar neurons. Science 248:223-226.

Prada C, Puelles L, Genis-Galvez JM (1981) A Golgi study on the early sequence of differentiation of ganglion cells in the chick embryo retina. Anat Embryol 161:305-317.

Prada C, Puga J, Pérez-Méndez L, Lopez R, Ramirez G (1991) Spatial and temporal patterns of neurogenesis in the chick retina. Eur $\mathbf{J}$ Neurosci $3: 559-569$.
Rager GH (1980) Development of the retinotectal projection in the chicken. Adv Anat Embryol Cell Biol 63:1-92.

Ramon y Cajal S (1911) Histologie du système nerveux de l'Homme et des vertébrés. vol. 2 (1972 reprint). Madrid: Instituto Ramon y Cajal.

Reh TA (1992) Cellular interactions determine neuronal phenotypes in rodent retinal cultures. J Neurobiol 23:1067-1083.

Sargent PB (1993) The diversity of neuronal nicotinic acetylcholine receptors. Annu Rev Neurosci 16:403-443.

Turner DL, Cepko CL (1987) A common progenitor for neurons and glia persists in rat retina late in development. Nature 328:131-136.

Turner DL, Snyder EY, Cepko CL (1990) Lineage-independent determination of cell type in the embryonic mouse retina. Neuron 4:833845.

Vandaele S, Nordquist DT, Feddersen RM, Tretjakoff I, Peterson AC, Orr HT (1991) Purkinje cell protein-2 regulatory regions and transgene expression in cerebellar compartments. Genes Dev 5:11361148 .

Waid DK, McLoon SC (1995) Immediate differentiation of ganglion cells following mitosis in the developing retina. Neuron 14:117-124.

Wang MM, Reed RR (1993) Molecular cloning of the olfactory neuronal transcription factor Olf-1 by genetic selection in yeast. Nature 364:121-126.

Wang Y, Macke JP, Merbs SL, Zack DJ, Klaunberg B, Bennett J, Gearhart J, Nathans J (1992) A locus control region adjacent to the human red and green visual pigment genes. Neuron 9:429-440.

Wetts R, Fraser SE (1988) Multipotent precursors can give rise to all major cell types of the frog retina. Science 239:1142-1145.

Whiting PJ, Schoepfer R, Conroy WG, Gore MJ, Keyser KT, Shimasaki $S$, Esch $\mathrm{H}$, Lindstrom JM (1991) Expression of nicotinic acetylcholine receptor subtypes in brain and retina. Mol Brain Res 10:61-70.

Williams RW, Goldowitz D (1992) Lineage versus environment in embryonic retina: a revisionist perspective. Trends Neurosci 15:368373.

Zack DJ, Bennett J, Wang Y, Davenport C, Klaunberg B, Gearhart J, Nathans J (1991) Unusual topography of bovine rhodopsin promoterlacZ fusion gene expression in transgenic mouse retinas. Neuron 6:187-199. 